\title{
A ROBERTSONIAN TRANSLOCATION IN BRITISH FRIESIAN CATTLE
}

\author{
D. L. POLLOCK AND J. G. BOWMAN \\ Department of Agriculture, The University, \\ Earley Gate, Reading RG6 2AT
}

(Received 14th March 1974)

\begin{abstract}
Summary. A Robertsonian translocation in the heterozygous condition was observed in a phenotypically normal Friesian bull. This chromosomal abnormality was probably transmitted by the dam, which also displayed heterozygosity. It is suggested that this cow could have been the original carrier. Chromosome studies on forty-six animals in the pedigree of the heterozygous bull are described.

Karyotypically normal cows (139) were inseminated with frozen semen from the bull and ninety-one calves were born. The distribution of the translocation and the sex ratio in the progeny group did not significantly deviate from 0.5 . One heterozygous male calf died from a septal cardiac defect but the association between the deformity and heterozygosity was considered coincidental. The fertility of the bull was normal and meiotic studies were undertaken after slaughtering.
\end{abstract}

\section{INTRODUCTION}

The normal karyotype of cattle (Bos taurus) comprises $2 n=60$ chromosomes of which fifty-eight are acrocentric autosomes and two are submetacentric sex chromosomes (Melander, 1959; Sasaki \& Makino, 1962; Gustavsson, 1969). Cytogenetic studies of individual animals and population samples from cattle breeds have revealed diploid chromosome numbers of 58 and 59 as well as 60 . The reductions in diploid number have been associated with the presence of either one or two large metacentric or submetacentric autosomes, thought to be the results of translocations of the Robertsonian or centric fusion type (Gustavsson, 1969; Pollock, 1972; Bruère \& Chapman, 1973). Some details of the three examples of Robertsonian translocation found in cattle are contained in Table 1.

The 1/29 translocation, which has now been observed in several breeds, was associated with impaired fertility in the Swedish Red breed, as daughter groups of heterozygous artificial insemination sires displayed lower non-return rates to service following insemination than daughter groups of sires with normal $60 \mathrm{XY}$ karyotypes, although the sires themselves were of normal fertility (Gustavsson, 1969).

Consequently, several populations of bulls in artificial insemination studs in other countries were screened and two further translocations were observed. Bruère \& Chapman (1973) described a metacentric autosome in a Simmental 
bull in New Zealand with a karyotype of $59 \mathrm{XYt}+$. Autosomes from homologous pairs 11 or 12 and 15 or 16 were thought to have been involved.

In 1972, Pollock found a centric fusion possibly comprising autosomes from pairs 2 and 4 in a phenotypically normal Friesian bull in England. This paper reports further studies undertaken on the bull (the proband), on animals in his pedigree, and on his offspring.

Table 1. Robertsonian translocation studies in cattle

\begin{tabular}{|c|c|c|c|c|c|}
\hline Author & Breed & Country & $\begin{array}{l}\text { No. of } \\
\text { carriers }\end{array}$ & Type & $\begin{array}{l}\text { No. of } \\
\text { animals }\end{array}$ \\
\hline Amrud (1969) & Norwegian Red & Norway & 31 & $1 / 29$ & 455 \\
\hline Bruère \& Chapman (1973) & $\begin{array}{l}\text { Blonde d'Aquitaine } \\
\text { Simmental }\end{array}$ & $\begin{array}{l}\text { New Zealand } \\
\text { New Zealand }\end{array}$ & $\begin{array}{l}1 \\
1\end{array}$ & $\begin{array}{c}1 / 29 \\
11-12 / \\
15-16\end{array}$ & $\begin{array}{r}5 \\
13\end{array}$ \\
\hline Darré et al. (1972) & $\begin{array}{l}\text { Limousin } \\
\text { Blonde d'Aquitaine }\end{array}$ & $\begin{array}{l}\text { France } \\
\text { France }\end{array}$ & $\begin{array}{l}8 \\
9\end{array}$ & $\begin{array}{l}1 / 29 \\
1 / 29\end{array}$ & $\begin{array}{l}57 \\
44\end{array}$ \\
\hline Gustavsson (1969) & Swedish Red & Sweden & 293 & $1 / 29$ & 2045 \\
\hline Gustavsson (1971) & $\begin{array}{l}\text { Swedish Red } \\
\text { Swedish Ayrshire }\end{array}$ & $\begin{array}{l}\text { Sweden } \\
\text { Sweden }\end{array}$ & $\begin{array}{r}118 \\
2\end{array}$ & $\begin{array}{l}1 / 29 \\
1 / 29\end{array}$ & $\begin{array}{r}923 \\
21\end{array}$ \\
\hline Harvey (1972) & $\begin{array}{l}\text { Charolais } \\
\text { Limousin } \\
\text { Red Poll } \\
\text { Simmental } \\
\text { Blonde d'Aquitaine }\end{array}$ & $\begin{array}{l}\text { Gt Britain } \\
\text { Gt Britain } \\
\text { Gt Britain } \\
\text { Gt Britain } \\
\text { France }\end{array}$ & $\begin{array}{r}24 \\
1 \\
1 \\
2 \\
1\end{array}$ & $\begin{array}{l}1 / 29 \\
1 / 29 \\
1 / 29 \\
1 / 29 \\
1 / 29\end{array}$ & $\begin{array}{r}187 \\
5 \\
42 \\
-\end{array}$ \\
\hline $\begin{array}{l}\text { Herschler \& Fechheimer } \\
\quad \text { (1966) }\end{array}$ & Holstein & U.S.A. & $\begin{array}{c}3 \\
\text { (triplets) }\end{array}$ & $1 / 29$ & 4 \\
\hline Herzog \& Hohn (1971) & Red Pied & Germany & 2 & $1 / 29$ & 5 \\
\hline Pollock (1972) & Friesian & Gt Britain & 1 & $2 / 4$ & - \\
\hline Popescu (1971) & Montbéliarde & France & 2 & $1 / 29$ & 2 \\
\hline $\begin{array}{l}\text { Rieck, Hohn \& Herzog } \\
\text { (1968) }\end{array}$ & Red Pied & Germany & 5 & $1 / 29$ & - \\
\hline Rugiati \& Fedrigo (1967) & Romagnola & Italy & 1 & $1 / 29$ & 1 \\
\hline
\end{tabular}

\section{MATERIALS AND METHODS}

The proband was first studied during a cytogenetic screening of all young bulls involved in progeny testing with the Milk Marketing Board of England and Wales in 1971 and 1972 (Pollock, 1972). In view of the possibility of fertility problems, the proband was removed from the regular progeny-testing scheme but permission to carry out a restricted number of test matings was obtained. Cows from experimental herds and selected dairy herds were inseminated with frozen semen from the proband. The calves born were cytogenetically examined around 10 days of age together with their dams. Forty-six animals in the pedigree of the proband, mainly on the maternal side, were identified and sampled. All cattle involved were pure bred British Friesian.

Mitotic chromosomes from each animal were prepared using a whole blood culturing method. When the proband was slaughtered, meiotic studies were undertaken and fibroblast cultures from kidney, liver and testis were initiated. 


\section{Cytogenetic techniques}

Leucocyte metaphases were obtained with a modification of the procedure first described by Moorehead, Nowell, Mellman, Battips \& Hungerford (1960). Heparinized vacutainers $(10 \mathrm{ml})$ were used to obtain blood from jugular veins and $0.3 \mathrm{ml}$ whole blood was added to $5.0 \mathrm{ml}$ tissue culture medium (Hams F 10, Flow Labs) supplemented with antibiotics, glutamine, heparin, phytohaemagglutinin and fetal calf serum. Two cultures were prepared from each blood sample. After incubation at 37 to $38^{\circ} \mathrm{C}$ for $48 \mathrm{hr}$, colchicine solution, giving a final concentration of $0.1 \mu \mathrm{g} / \mathrm{ml}$ culture, was added for $2 \frac{1}{2} \mathrm{hr}$. The leucocytes were treated hypotonically with a $0.7 \%$ trisodium citrate solution for $25 \mathrm{~min}$ at $38^{\circ} \mathrm{C}$ before being fixed in a $3: 1 \mathrm{v} / \mathrm{v}$ methanol:glacial acetic acid fixative. Three fixative changes were given before the cells were dropped on slides using the air-drying technique, and then stained in a 1:10 Giemsa solution for $10 \mathrm{~min}$. Banding patterns were produced by the trypsinization treatment of Seabright (1971) followed by Giemsa staining.

The fibroblast cultures were prepared according to the specifications of Basrur, Basrur \& Gilman (1963) $2 \mathrm{hr}$ after the excision of the tissue samples. The cultures lasted for 12 days and the hypotonic, fixation and staining procedures were the same as for the whole blood cultures.

The meiotic preparations, initiated in the slaughterhouse immediately after the bull was killed, were undertaken using the technique of Evans, Breckon \& Ford (1964). The hypotonic treatments were $0.7 \%$ and $0.85 \%$ trisodium citrate solutions. One fixative change was carried out in the slaughterhouse and a further three in the laboratory, after which the cells were dropped on slides, stained and mounted. A colchicine pretreatment was not administered.

\section{RESULTS}

\section{The proband}

Including the data from Pollock (1972), a total of 570 metaphases from six blood samples taken from the proband over a 15 -month period were examined and $527(92.5 \%)$ exhibited a karyotype of $59 \mathrm{XYt}+(\mathrm{Pl}$. 1, Fig. 1) while $4.0 \%$ were apparently tetraploid. A study of eighty-three fibroblast cells at metaphase showed seventy-five $(90.4 \%)$ with the modal $59 \mathrm{XYt}+$ and eight aneuploid cells. Evidence of mosaicism in these cell lines was not observed.

Details of the observations made on the meiotic cells are given in Table 2. In several spermatogonial metaphase plates, the chromosomes were poorly defined but in easily discernible cells the metacentric autosome and the sex chromosomes were always present. During leptonema, zygonema and pachynema, a spherical heteropyknotic sex vesicle was visible but the centric fusion was not seen until diplonema and subsequent stages. At diakinesis, $85.4 \%$ of the cells carried twenty-nine configurations including a chain trivalent (Pl. 2, Fig. 1). Six different karyotypes were noted in thirty-four secondary spermatocyte metaphases and all but two were balanced. Interpretation difficulties were partly overcome by grouping the cells according to the presence or absence of the Robertsonian translocation before numerical assessment was carried out (Pl. 2, Fig. 2) with repetition of the process after 1 month. 
Table 2. Numbers and types of cells examined in the meiotic preparations from the Friesian bull proband

\begin{tabular}{l|c|c|c}
\hline \multicolumn{1}{c|}{ Stage } & $\begin{array}{c}\text { No. of } \\
\text { cells examined }\end{array}$ & Karyotype & $\begin{array}{c}\text { No. of } \\
\text { configurations }\end{array}$ \\
\cline { 2 - 4 } Spermatogonial metaphase & 34 & $59 \mathrm{XYt}+$ & - \\
Pachytene & 4 & $118 \mathrm{XYXYt}+\mathrm{t}+$ & - \\
Diplotene & 20 & - & 29 \\
Diakinesis & 9 & - & 29 \\
& 210 & - & 29 \\
& 12 & - & $\leqslant 28$ \\
Secondary spermatocyte metaphase & 19 & - & 58 \\
& 5 & $30 \mathrm{X}$ & - \\
& 9 & $30 \mathrm{Y}$ & - \\
& 6 & $29 \mathrm{Xt}+$ & - \\
& 5 & $29 \mathrm{Yt}+$ & - \\
& 1 & $31 \mathrm{Yt}+$ & - \\
\hline
\end{tabular}

Animals in the pedigree of the proband

The five paternal half-brothers of the proband, in service with the Milk Marketing Board artificial insemination scheme, displayed normal 60XY karyotypes which indicated, though not significantly, the normality of the chromosome complement of the sire of the proband, assuming an expected frequency of 0.5 for heterozygotes $\left(\chi^{2}=3.7, P>0.05\right)$. The dam of the proband was a 14-year-old cow from which 320 leucocytes from three blood samples taken over a 12-month period were examined. A total of 305 cells possessed the karyotype $59 \mathrm{XXt}+$ with a metacentric chromosome similar to that of the proband. As this animal was still alive, tissue samples for fibroblast culture were not procured. The proband was her ninth calf and Text-fig. 1 illustrates those

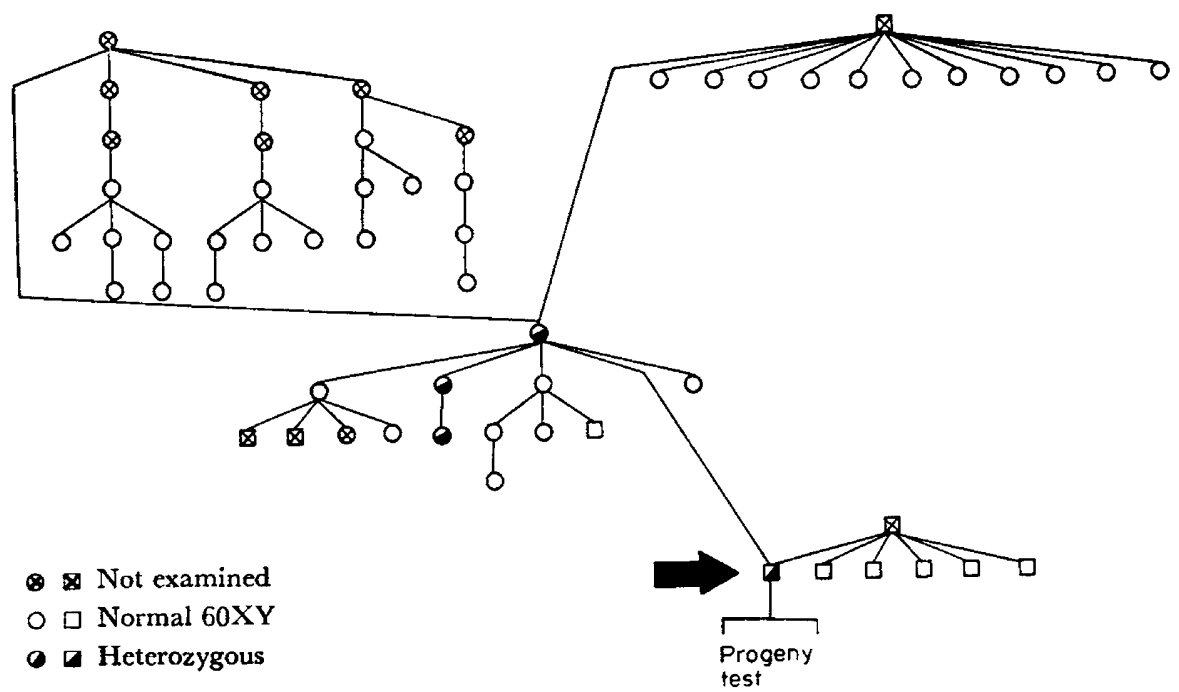

TEXT-FIG. 1. The pedigree of the proband (arrowed). Circles represent females, squares represent males. 


\section{de ha an a da do an Knan a a on na do na da an en an on a no na - no no na na a ne na no no nuan a an no an a a na na ha na an bo a

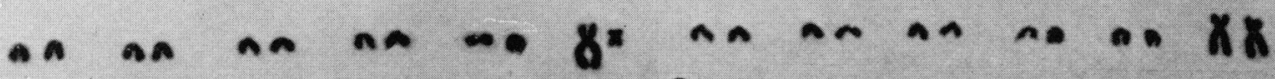 2}

Fig. 1. Karyotype from the Friesian bull proband, 59XYt.$+ \times 1440$.

Fig. 2. Karyotype from the dam of the Friesian bull proband, $59 \mathrm{XXt}+. \times 1440$.

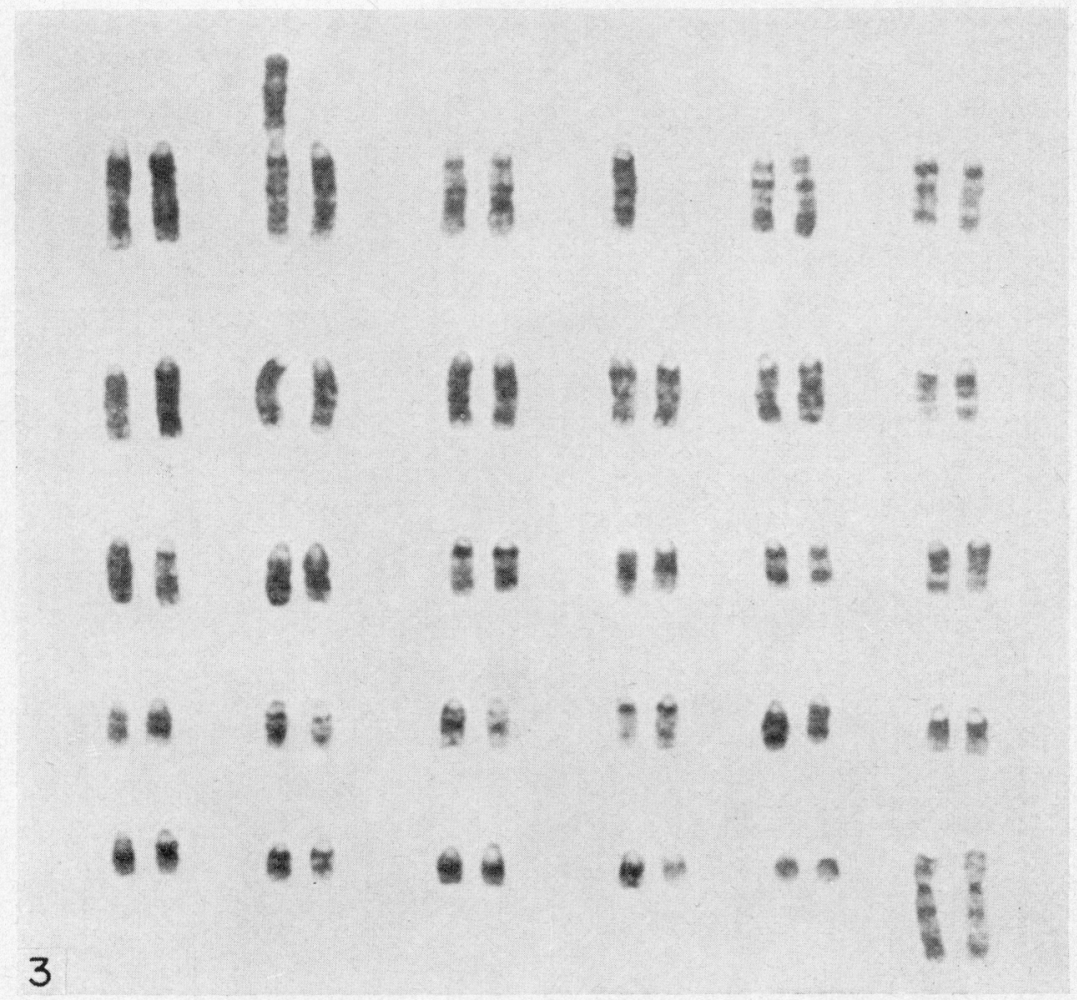

Fig. 3. Banded karyotype from a heterozygous daughter of the Friesian bull proband. $\times 1800$. 


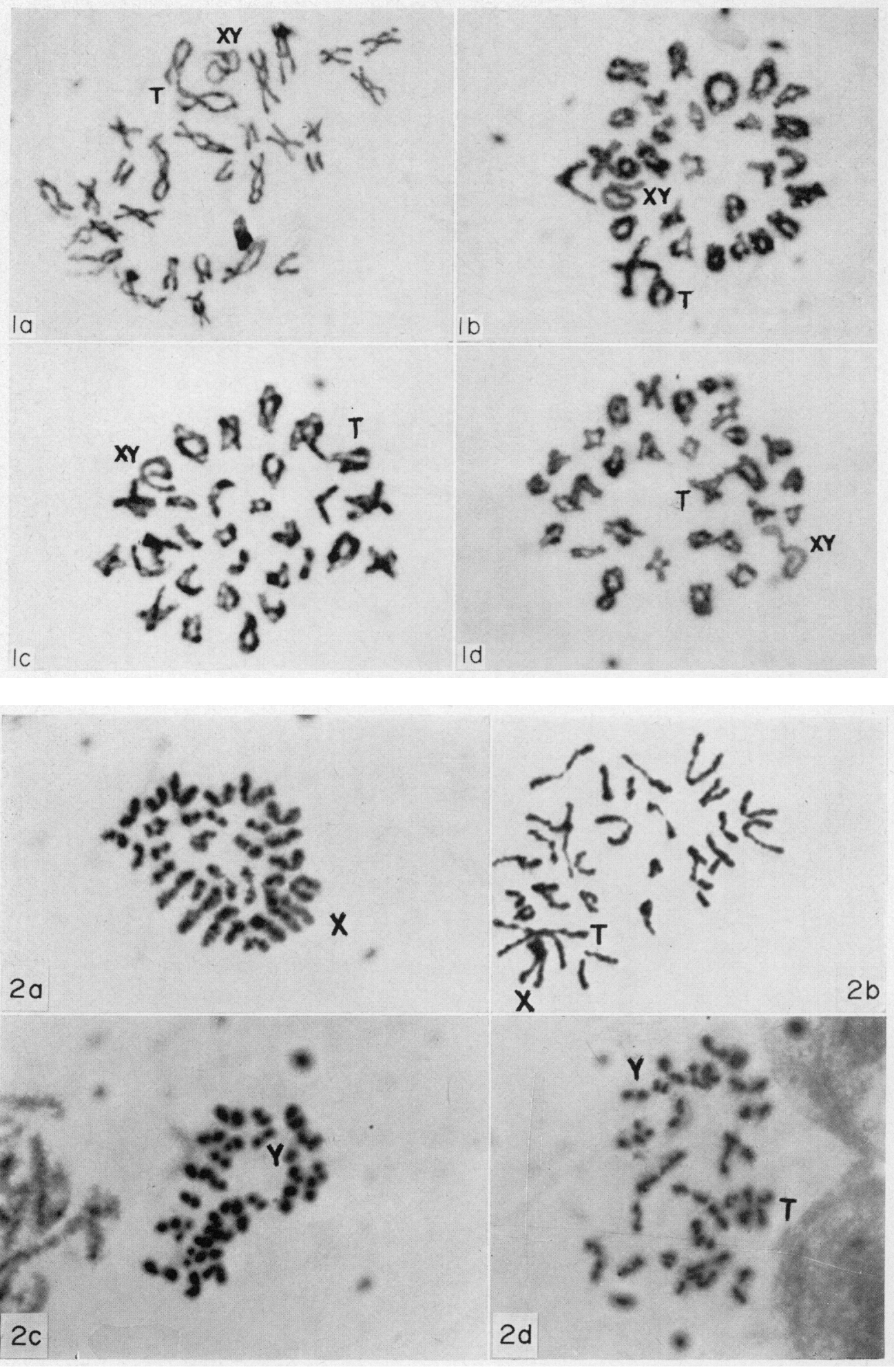

(Facing p. 427) 
of her progeny which were examined cytogenetically, and the segregation behaviour of the Robertsonian translocation. A karyotype from the dam is shown in Pl. 1, Fig. 2.

Table 3. Details of the dams and calves in the progeny test of the Friesian bull proband

\begin{tabular}{c|c|cccc|c|c}
\hline Farm & $\begin{array}{c}\text { No. of } \\
\text { cows }\end{array}$ & $60 \mathrm{XY}$ & $\begin{array}{c}\text { Progeny karyotypes } \\
59 \mathrm{YXt}+\end{array}$ & $60 \mathrm{XX}$ & $59 \mathrm{XXt}+$ & $\begin{array}{c}\text { No. of calves } \\
\text { born alive }\end{array}$ & $\begin{array}{c}\text { No. of calves } \\
\text { stillborn }\end{array}$ \\
\hline A & 12 & 5 & 2 & 1 & 3 & 11 & - \\
B & 34 & 7 & 3 & 5 & 4 & 19 & - \\
G & 6 & 3 & 1 & -1 & - & 4 & - \\
D & 12 & 1 & 2 & 1 & 3 & $7 *$ & - \\
E & 12 & 5 & - & 1 & 3 & 9 & - \\
F & 51 & 9 & 10 & 10 & 8 & 37 & - \\
G & 12 & 1 & - & - & 1 & 2 & - \\
Total & 139 & 31 & 18 & 18 & 22 & 89 & 2 \\
\hline
\end{tabular}

* This figure includes one pair of heterosexual twins which displayed $60 \mathrm{XY} / 59 \mathrm{XXt}+$ chimaerism. To complete the segregation data, the male twin calf was included in the 60XY column and the female co-twin in the $59 \mathrm{XXt}^{+}+$column.

Table 4. Details of the inseminations and the fertility of the Friesian bull proband from the progeny test

\begin{tabular}{c|c|c|c|c|c}
\hline Farm & $\begin{array}{c}\text { No. } \\
\text { of first } \\
\text { inseminations }\end{array}$ & $\begin{array}{c}\text { No. } \\
\text { of second } \\
\text { inseminations }\end{array}$ & $\begin{array}{c}\text { No. } \\
\text { of third } \\
\text { inseminations }\end{array}$ & $\begin{array}{c}\text { Calving rate to } \\
\text { first inseminations } \\
(\%)\end{array}$ & $\begin{array}{c}\text { Calving rate to } \\
\text { all inseminations } \\
(\%)\end{array}$ \\
\hline A & 12 & 2 & - & 90.0 & 78.6 \\
B & 34 & - & - & 55.9 & 55.9 \\
C & 6 & 3 & - & 50.0 & 44.4 \\
D & 12 & - & - & 50.0 & 50.0 \\
E & 12 & 12 & -1 & 52.0 & 60.0 \\
F & 51 & 1 & - & 8.3 & 60.9 \\
G & 12 & 21 & 1 & 51.7 & 15.4 \\
Total & 139 & 1 & & 56.5 \\
\hline
\end{tabular}

The maternal grandsire of the proband was slaughtered in 1961 but eleven daughters, half-sisters to the dam of the proband, all showed normal $60 \mathrm{XX}$ karyotypes. This finding, assuming an expected heterozygote frequency of 0.5 , suggested that this bull was normal $\left(\chi^{2}=9 \cdot 4, P<0.01\right)$. The maternal granddam of the proband was the founder member of a strain of pedigree British Friesian cattle into which sixty-four females had been born. Eighteen of them (Text-fig. 1), aged from 3 months to 13 years, showed normal female karyotypes when examined. At least thirty-five metaphases from each animal were studied.

\section{EXPLANATION OF PLATE 2}

Figs 1 (a) to 1 (d). Cells at diakinesis prepared from the Friesian bull proband. $T$ is an abbreviation for trivalent; XY demonstrates the sex chromosome bivalent. $\times 1950$.

Figs 2(a) to 2(d). Secondary spermatocyte metaphases from the Friesian bull proband.

$\mathrm{T}$ is an abbreviation for Robertsonian translocation; $\mathrm{X}=$ female sex chromosome;

$\mathrm{Y}=$ male sex chromosome. $\times 2500$. 
Animals from the progeny test of the proband

A total of 139 Friesian cows with normal karyotypes were inseminated with frozen semen from the proband. Details of the calves born, and inseminations and fertility are listed in Tables 3 and 4 . No checks of parentage were necessary as the semen from the proband was used for first inseminations after calving and when repeat services with semen from other sires were carried out, the cows were removed from the scheme. With the exception of a set of heterosexual twins from Farm D (Table 3) which displayed sex chromosome chimaerism and centric fusion chimaerism, the calves were singly born. As two male calves were stillborn, the karyotypes of eighty-nine of the ninety-one offspring were studied and the distribution of the Robertsonian translocation in the progeny group is shown in Table 3. One male heterozygous calf at birth had an accelerated heart beat and respiration rate. When the animal died at 14 days, a postmortem examination revealed a $1 \cdot 2-\mathrm{cm}$ interventricular foramen. All other calves were of normal phenotype and at least thirty-five metaphases were studied from each animal. A banded karyotype from one of the female heterozygous progeny is shown in Pl. 1, Fig. 3.

\section{DISCUSSION}

Incidence and origin

This Robertsonian translocation is the first to be identified in British Friesian cattle and has not been found in other breeds of cattle or in other strains of Holsteins/Friesians. The banded karyotype showed that, according to the idiogram of the authors, the second and fourth autosomes were probably involved, as previously suggested (Pollock, 1972). This idiogram may, however, have been different from those prepared by other workers and it would be advantageous if standard banded karyotypes for cattle, and possibly other agriculturally important animals, were compounded.

The frequency of the Robertsonian translocation in the sample of bulls was $0.3 \%$. With the inclusion of all reports on Holstein/Friesian bulls in the literature, this figure becomes $0.1 \%$. This is considerably lower than the frequencies found for the 1/29 translocation in the Swedish Red (Gustavsson, 1969, 1971), Limousin and Blonde d'Aquitaine (Darré, Quéinnec \& Berland, 1972) and for the Massey 1 in Romney sheep (Bruère \& Mills, 1971) but closer to the frequency estimated by Court Brown (1967) for structural polymorphism in man. Assuming there is no selective disadvantage in carrying this Robertsonian translocation, the possibility that the abnormality arose recently is one explanation of the apparent low frequency. The observation of a heterozygous karyotype in the dam of the proband indicated that she was the most likely source of the translocation in the proband, but the origin in this cow remained obscure. It was unlikely that her sire had been a carrier since eleven daughters all displayed normal female karyotypes. The discovery of eighteen normal karyotypes in the pedigree strain, assuming a probability of inheritance of 0.5 with heterozygosity and no homozygosity, suggested that the maternal grand-dam of the proband was more likely to have been heterozygous or mosaic than homozy- 
gous. The postulation that this cow had been a carrier, however, was based on the heterozygosity of one animal, the dam of the proband. As the relationship between the two cows was not tested by blood group comparisons, the mistaken identity of one of them remains a possibility.

The centric fusion could have arisen de novo during gametogenesis or embryogenesis. As there was no evidence of mosaicism in the leucocyte sample studied or from the segregation data in the cow's progeny group, it can be suggested that the Robertsonian translocation came about during gametogenesis or during early cleavage division, the aberrant clone having given rise to the fetus proper. Therefore, it is possible that the dam of the proband was the original carrier of this structural variation, but this cannot be assumed with any certainty as inheritance cannot be eliminated.

\section{Segregation of the trivalent}

Hamerton (1971) described the possible gametic products of adjacent and alternate segregation from a chain trivalent during anaphase I. Aneuploid karyotypes indicative of adjacent segregation were not identified in calves from the progeny test and the ratio of heterozygous to normal karyotypes was 49 to 40 and not significantly different from a 0.5 distribution $\left(\chi^{2}=0.9, P>0.3\right)$. When expected frequencies of $0 \cdot 25$ were applied to the four karyotypes $(60 \mathrm{XY}$, $60 \mathrm{XX}, 59 \mathrm{XYt}+, 59 \mathrm{XXt}+)$, a significant deviation was not recorded $\left(\chi_{3}^{2}=5 \cdot 1\right.$, $P>0 \cdot 10)$ which indicated that the sex chromosomes and the Robertsonian translocation were segregating independently.

As the expected frequencies were based on results from studies on Robertsonian translocations comprising other autosomes (Gustavsson, 1969; Padeh, Wysoki \& Soller, 1971; Bruère \& Mills, 1971), it was thought advisable to apply a test for heterogeneity. From the two-way table of sex against normal homozygosity and heterozygosity, a non-significant value was obtained $\left(\chi_{\text {het }}^{2}=2.96, P>0.05\right)$. Further evidence for a 0.5 distribution of the Robertsonian translocation came from the study of the secondary spermatocytes in which the number of cells with the metacentric chromosome did not deviate significantly from the number without $\left(\chi^{2}=1.9, P>0 \cdot 10\right)$ and differences between the sexes was small $\left(\chi^{2}=0.5, P>0.3\right)$. The total number of secondary metaphases examined, however, was probably inadequate considering the quantity of such cells in bovine testes.

In comparable matings, a segregation ratio of 0.5 for Robertsonian heterozygotes and lack of aneuploid progeny were also found by Gustavsson (1969), Amrud (1969) and Harvey (1971) in cattle, by Bruère \& Mills (1971) in sheep and by Padeh et al. (1971) and Popescu (1972) in goats. Examples of trisomy have been found infrequently in calves with brachygnathia inferior and other congenital abnormalities (Herzog \& Hohn, 1968; Mori, Sasaki, Makino, Ishikawa \& Kawata, 1969; Hohn \& Herzog, 1970; Dunn \& Johnson, 1972), but these were primary in nature and the chromosomes involved were not positively identified. Trisomy involving large chromosomes may have severe effects in ontogeny and viable aneuploid progeny might not be expected (Fechheimer, 1968). A corresponding reduction in fertility might therefore be expressed. 


\section{Phenotypic effects of the Robertsonian translocation}

The 30- to 60-day non-return rate to first insemination after calving shown by the proband was $71.8 \%$, which lay in the range displayed by 120 contemporary bulls with normal $60 \mathrm{XY}$ karyotypes though it was slightly below the mean of $73.9 \%$. The percentage calving rate to first insemination was similar to that found in 1972 by D. L. Stewart (personal communication) using frozen semen from Friesian bulls. The unbalanced secondary spermatocyte karyotypes observed may have been technical artifacts, indicating that aneuploid spermatozoa would not have been produced. If the imbalance was genuine and indicative of aneuploid spermatozoa, however, the apparent normal fertility of the proband may be explained by the reduction of the effectiveness of such spermatozoa through freezing, and matings with fresh semen would have given some control. There is recent evidence of a differential loss of fertilizing ability of spermatozoa after deep freezing semen from Friesian bulls (Stewart, Spooner, Bennett, Beatty \& Hancock, 1974).

Hamerton (1971) and White (1973) have suggested that an asymmetrical trivalent was more likely to be associated with non-disjunction or adjacent segregation than a symmetrical trivalent, which could explain the lack of aneuploid progeny in this case as well as the normal fertility levels of the proband. Recently, however, Cattanach \& Moseley (1973) found no evidence of a relationship between the geometry of chain trivalents and non-disjunction in their study of mice hybrids. Other studies in man (Penrose \& Smith, 1966; Hamerton, 1971) and mice (Eicher, 1973) indicate that non-disjunction or adjacent segregation is less likely to occur in male Robertsonian translocation carriers than in female heterozygotes. Such an occurrence would explain the findings of Gustavsson (1969) in the Swedish Red breed but as no female fertility data were collected in the present study, it cannot be applied to this Robertsonian translocation. The twenty-two heterozygous daughters born to the proband have been assembled on five farms in order that their reproduction records can be monitored over the next few years.

The relationship between heterozygosity for the Robertsonian translocation and cardiac septal defects appeared to be coincidental as only one out of the forty-four carriers displayed the abnormality. Congenital defects in cattle have frequencies ranging from $0.2 \%$ to $3.6 \%$ (Greene, Leipold, Huston, Noordsy \& Dennis, 1973; Salisbury \& VanDemark, 1960; Leipold, Dennis \& Huston, 1972). Shive, Hare \& Patterson (1965) studied fifteen dogs with congenital cardiac defects and found one animal heterozygous for a Robertsonian translocation. In chromosomal studies in cattle (Amrud, 1969; Gustavsson, 1969; Harvey, 1971; Pollock, 1972; Bruère \& Chapman, 1973), sheep (Bruère \& Mills, 1971), goats (Padeh et al., 1971; Popescu, 1972) and man (Hamerton, 1971), there has been no mention of any relationship between heterozygous karyotypes and congenital cardiac abnormalities and such an association may not, in fact, exist.

\section{AGKNOWLEDGMENTS}

The authors would like to thank the Milk Marketing Board Veterinary Divi- 
sion, in particular Mr G. F. Smith, Mr A. D. Forteath, Mr E. J. Simmons, $\mathrm{Mr}$ J. Stables, Mr T. H. Jones and Mr A. Carter for their interest and assistance, and the many farmers and farm managers who cooperated with the project. We are grateful to the late $\operatorname{Dr}$ M. W. H. Bishop for providing slaughtering facilities for the proband and to Mrs M. Seabright for demonstrating her banding pattern technique. Financial support for the work was given by the Department of Agriculture and Fisheries for Scotland and the Milk Marketing Board.

\section{REFERENGES}

AmRUd, J. (1969) Gentric fusion of chromosomes in Norwegian Red cattle. Hereditas, 62, 293.

BASRUR, P, K., BASRUR, V. R. \& Gilman, J. P. W. (1963) A simple method for short term cultures from small biopsies. Expl Cell Res. 30, 229.

Bruère, A. N. \& Chapman, H. M. (1973) Autosomal translocations in two exotic breeds of cattle in New Zealand. Vet. Rec. 92, 615.

BRUÈre, A. N. \& Mills, R. D. (1971) Observations on the incidence of Robertsonian translocations and associated testicular changes in a flock of New Zealand Romney sheep. Cytogenetics, 10, 260.

Cattanach, B. M. \& Moseley, H. (1973) Nondisjunction and reduced fertility caused by the tobacco mouse metacentric chromosomes. Cytogenet. Cell Genet. 12, 264.

Court Brown, W. M. (1967) Human Population Cytogenetics. North Holland Publishing Co., Amsterdam.

Darre, R., Quérnnec, G. \& BerLand, H. M. (1972) La translocation 1-29 des Bovins. Etude générale et importance du phénomène dans le Sud-Ouest. Revue méd. vet. 123, 477.

Dunn, H. O. \& Johnson, R. D. (1972) A $61 \mathrm{XY}$ cell line in a calf with extreme brachygnathia. 7. Dairy Sci. 55, 524.

EICHER, E. M. (1973) Translocation trisomic mice; production by female but not male translocation carriers. Science, N.Y. 180, 81.

Evans, E. P., Breckon, G. \& Ford, G. E. (1964) An air drying method for meiotic preparations from mammalian testes. Cytogenetics, 3, 289.

FechHeimer, N. S. (1968) Consequences of chromosomal aberrations in mammals. J. Anim. Sci. 27, Suppl. 1, 27.

Greene, H. J., Leipold, H. W., Huston, K., Noordsy, J. L. \& Dennis, S. M. (1973) Gongenital defects in cattle. Irish Vet. F. 27, 37.

Gustavsson, I. (1969) Cytogenetics, distribution and phenotypic effects of a translocation in Swedish cattle. Hereditas, 63, 68.

Gustavsson, I. (1971) Distribution of the 1-29 translocation in the A.I. bull population of Swedish Red and White cattle. Hereditas, 69, 101.

Hamerton, J. L. (1971) Human Cytogenetics, Vol. 1. Academic Press, New York and London.

Harvey, M. J. A. (1971) An autosomal translocation in the Charolais breed of cattle. Vet. Rec. 89, 110.

HaRVey, M. J. A. (1972) Chromosome abnormalities of cattle in Britain. Vet. Rec. 91, 630.

Herschler, M. S. \& Fechreimer, N. S. (1966) Centric fusion of chromosomes in a set of bovine triplets. Cytogenetics, 5, 307.

Herzog, A. \& HoHN, H. (1968) Autosomal trisomy in a calf with brachygnathia inferior and congenital ascites. Dt. tierärztl. Wschr. 75, 225.

Herzoc, A. \& HoHN, H. (1971) Zytogenetische befunde bei angeborenen anomalien ces zentralnervensystem des rindes. Annls gen. Sel. anim. 3, 225.

Hohn, H. \& Herzoc, A. (1970) Zwei weitre falle von autosomaler trisomie bei kalbern mit brachygnathia inferior und anderen missbildungen. Giessen. Beitr. Erbpath. Zuchthyg. 3, 1.

Leipold, H. W., Dennis, S. M. \& Huston, K. (1972) Congenital defects in cattle. Adv. vet. Sci. 16, 103.

MeLANDER, Y. (1959) The mitotic chromosomes of some cavicorn animals. Hereditas, 49, 649.

Moorehead, P. S., Nowell, P. C., Mellman, W. J., Battips, D. M. \& Hungerford, D. A. (1960) Ghromosome preparations of leucocytes cultured from human peripheral blood. Expl Cell Res. 20,613.

Mori, M., Sasaki, M., Makino, S., Ishikawa, T. \& Kawata, I. (1969) Autosome trisomy in a malformed newborn calf. Proc. Japan Acad. 45, 955.

PADEh, B., WYsokI, M. \& Soller, M. (1971) Further studies on a Robertsonian translocation in Saanen dairy goats. Cytogenetics, 10,61.

Penrose, L. S. \& Smrth, G. F. (1966) Downs Anomaly. Churchill, London.

Pollock, D. L. (1972) A chromosome abnormality in Friesian cattle in Great Britain. Vet. Rec. 90, 309.

Popescu, C-P. (1971) Deux cas nouveaux de fusion centrique chez les bovins. Annls gen. Sel. anim. 3, 521. 
Popescu, G-P. (1972) Mode de transmission d'une fusion centrique dans la descendence d'un bouc heterozygote. Annls gen. Sel. anim. 4, 355.

Rieck, G. W., Hohn, H. \& Herzog, A. (1968) Familial occurrence of a centromeric fusion in cattle. Zuchthygiene, $3,177$.

Rugiati, S. \& FedRIgo, M. (1967) Alterazione cromosomica riconstrata in un toro acondroplasico di razza romagnola. Acta Bio-medica, 38, 5 .

Salisbury, G. W. \& VanDemark, N. L. (1960) Physiology of Reproduction and Artificial Insemination in Cattle. Freeman and Co., San Francisco and London.

SASAKI, M. S. \& Makino, S. (1962) Revised study of the chromosomes of domestic cattle and the horse. 7. Hered. 53, 157.

SEABRIGHT, M. (1971) A rapid banding technique for human chromosomes. Lancet, ii, 971.

Shive, R. J., Hare, W. G. D. \& Patterson, D. F. (1965) Chromosome anomalies in dogs. Cytogenetics, 4,340 .

Stewart, D. L., Spooner, R. L., Bennett, G. H., Beatty, R. A. \& Hancock, J. L. (1974) A second experiment with heterospermic inseminations in cattle. F. Reprod. Fert. 36, 107.

White, M. J. D. (1973) Animal Cytology and Evolution, 3rd edn. Cambridge University Press. 